\title{
OCCURRENCE OF NOXIOUS WEEDS UNDER DIFFERENT SOIL MANAGEMENT SYSTEMS
}

\author{
Melo, A. K. P. ${ }^{1}-$ Albuquerque, J. A. A. ${ }^{*}-$ Siqueira, R. H. S. ${ }^{2}-$ Silva, E. E. $^{3}-$ \\ Medeiros, R. D. ${ }^{3}-$ SouZA, K. T. S. ${ }^{1}-$ SouZA, L. T. ${ }^{1}-$ GonÇALVES, A. C. M. ${ }^{1}-$ \\ SOARES, M. B. B. ${ }^{4}$ \\ ${ }^{1}$ Federal University of Roraima (UFRR), BR 174, Km 12, S/N $\mathrm{N}^{o}$ Campus do Cauamé, Bairro \\ Monte Cristo, Boa Vista, Roraima, CEP 69310-250, Brazil \\ (phone: +55-95-3627-2573) \\ ${ }^{2}$ Federal Institute of Roraima (IFRR), Rodovia Antonino Menezes da Silva, Km 03, S/N , \\ Campus do Amajari, Amajari, Roraima, CEP 69343-000, Brazil \\ (phone: +55-95-3593-1119) \\ ${ }^{3}$ Brasilian Agricultural Research Corporation (EMBRAPA-RR), Rodovia BR 174, Km 8, \\ Distrito Industrial, Boa Vista, Roraima, CEP 69301-970, Brazil \\ (phone: +55-95-4009-7100) \\ ${ }^{4}$ Researcher at Agribusiness Technology Agency of São Paulo (APTA), Rodovia Washington \\ Luiz, Km 372, Pindorama, São Paulo, CEP 15830-000, Brazil \\ (phone: +55-17-3572-1592) \\ ${ }^{*}$ Corresponding author \\ e-mail:anchietaufrr@gmail.com
}

(Received $26^{\text {th }}$ Sep 2019; accepted $8^{\text {th }}$ Jan 2020)

\begin{abstract}
The aim of this work was to identify weed species in areas under different soil management systems. The research was carried out in the Brazilian Agricultural Research Corporation experimental area, in the 2017/2018 harvest, in the city of Boa Vista, Roraima State, Brazil. The experimental design was randomized blocks and the treatments included of five soil management systems (native vegetation, minimum tillage, no-tillage, conventional tillage and conventional tillage with crop rotation). Weed collection, identification, counting and drying were performed and then the phytosociological indices (Relative density, relative frequency, relative abundance, importance value index, relative importance value index and dry mass) were calculated. Variance analysis with means compared by Tukey test $(\mathrm{P}<0.05)$, group analysis by hierarchical and non-hierarchical method, and principal component analysis were performed. Correlation coefficients of the variables were estimated. No and minimum tillage systems had the lowest weed rates per square meter. The botanical families Poaceae, Fabaceae and Rubiaceae are the most representative in the studied systems. Concerning relative frequency, the species Cyperus flavus stood out in all treatments other than native vegetation.
\end{abstract}

Keywords: no-till, spontaneous plants, phytosociological parameters, cover plant, native vegetation

\section{Introduction}

The use of the same weed control methods every year in the cultivation area is not recommended because their efficiency is diminished due to selection of species resistant or adapted to such management and, therefore, over time, this practice becomes economically unviable. According to Junior et al. (2019) the lack of proper management in modern agriculture results in low productivity, which is a characteristic problem in crops. 
Conservationist systems such as no-tillage and minimum tillage have been re-studied and adopted in order to improve soil physical, chemical and biological conditions and reduce production costs, such as weed control.

Prior knowledge of the main noxious weeds that could affect the next production cycle would help in targeted and precise control (Délye et al., 2013; Alcântara Neto et al., 2019; Menezes et al., 2019) aiming at system sustainability.

Phytosociology is the floristic and structural study of plant communities that requires the identification of species and classification of the most important ones. Phytosociological data contains relevant information for proper weed management in agricultural systems. This science covers one of the most commonly used methods for floristic recognition in agricultural or non-agricultural areas (Lima et al., 2014).

Phytosociological surveys in cultivated areas promote knowledge on weed populations, as well as knowledge of their morphological characteristics, such as: propagation type, life cycle, growth habit and photosynthetic route. The data obtained, when analyzed together, will indicate the most appropriate control method to be used (Cruz et al., 2010; Albuquerque et al., 2013, 2014).

The article aimed to analyze noxious weeds found under different soil management systems in Boa Vista, Brazil, in 2017-2018, through a randomized block design of five treatments, in order to collect phytosociological data for proper weed management in the region.

\section{Material and methods}

\section{Research location and period}

The research comprised an experiment conducted in the 2017/2018 agricultural years harvests, under different soil management systems. The experiment was conducted the Brazilian Agricultural Research Corporation [EMBRAPA] "Água Boa" Experimental Field, located at $30 \mathrm{~km}$ from Boa Vista, Roraima, Brazil, on the left bank of BR-174, toward the city of Manaus, Amazonas, Brazil. The experimental area has 1,200 ha and is situated between the geographic coordinates $02^{\circ} 39^{\prime} 00^{\prime \prime}$ and $02^{\circ} 41^{\prime} 10^{\prime \prime}$ north latitude and $60^{\circ} 49^{\prime} 40^{\prime \prime}$ and $60^{\circ} 52^{\prime} 20^{\prime \prime}$ west longitude from Greenwich.

The vegetation is represented by graminosa and arboreal species (Vale Júnior and Schaefer, 2010), with predominance of creeping species of the genera Trachypogon spp and Andropogon spp.

\section{Soil classification}

The soil of the area is classified as Medium Texture Yellow Argisoil distrocoeso (consistent). The soil physico-chemical analysis is presented in Table 1.

Table 1. Physical and chemical analysis of the soil in the $0-20 \mathrm{~cm}$ layer of the study area not incorporated in the production system, in the savannah of Roraima, Brazil

\begin{tabular}{|c|c|c|c|c|c|c|c|c|c|c|c|c|c|}
\hline \multicolumn{14}{|c|}{ Chemical Properties } \\
\hline Depth & $\mathrm{pH}$ & $\mathrm{OM}$ & $\mathrm{K}$ & $\mathrm{Ca}$ & $\mathrm{Mg}$ & $\mathrm{H}+\mathrm{Al}$ & $\mathrm{P}$ & $\mathrm{S}$ & $\mathrm{Cu}$ & $\mathrm{Fe}$ & $\mathrm{Zn}$ & $\mathrm{Mn}$ & $\mathrm{B}$ \\
\hline $0 \quad 20 \mathrm{~cm}$ & & $\mathrm{~g} \mathrm{dm}^{-3}$ & \multicolumn{4}{|c|}{----cmolc dm dm------- $^{-1}$} & \multicolumn{7}{|c|}{----------------- Mg dm'-3 ------------ } \\
\hline U- $20 \mathrm{~cm}$ & 4.1 & 1.1 & 0.01 & 0.3 & 0.2 & 0.8 & 3.0 & 3.0 & 0.1 & 30 & 0.2 & 0.6 & 0.39 \\
\hline \multicolumn{14}{|c|}{ Physical Properties $\left(\mathrm{g} \mathrm{kg}^{-1}\right)$} \\
\hline Depth & \multicolumn{5}{|c|}{ Clay } & \multicolumn{4}{|c|}{ Sand } & \multicolumn{4}{|c|}{ Silt } \\
\hline $0-20 \mathrm{~cm}$ & \multicolumn{5}{|c|}{200} & \multicolumn{4}{|c|}{760} & \multicolumn{4}{|c|}{40} \\
\hline
\end{tabular}




\section{Description and conduct of the experiment}

The experimental design was randomized blocks with five treatments and four replications. The treatments consisted of five soil management systems (native vegetation, minimum tillage, no-tillage system, conventional tillage system and conventional tillage system with crop rotation). The dimensions of the experimental plots were $10 \times 10\left(100 \mathrm{~m}^{2}\right)$ and the treatment areas were $101 \times 131 \mathrm{~m}$.

Related crops with year of cultivation: no-till (soybean + brachiaria), minimum tillage (soybean + brachiaria), conventional tillage with rotation (soybean + brachiaria), conventional planting (soybean) and native vegetation (fallow).

The phytosociological survey was performed following the inventory square method (Braun-Blanquet, 1979) with the aid of a cast iron square with dimensions of $0.50 \times 0.50 \mathrm{~m}$, randomly thrown four times in each of the treatments. Weeds were cut close to the ground, stored in plastic bags and taken to the laboratory, where they were quantified and identified with the aid of specialized literature (Lorenzi, 2000, 2014; Moreira and Bragança, 2010). Initially weeds were identified at class, family, scientific name, common name and described the type of propagation, growth habit, life cycle, photosynthetic route and coding of the European and Mediterranean Plant Protection Organization [EPPO].

Descriptive analysis of the following phytosociological parameters was performed: 1 . Relative density $[\mathrm{RD}]=$ Species density x 100 / total density of all species; 2 . Relative frequency $[R F]=$ Species frequency $x 100 /$ Total frequency of all species; 3 . Relative abundance $[\mathrm{RA}]=$ Species abundance $\times 100 /$ total abundance of all species; 4 . Importance Value Index [IVI] = RD + RF + RDo; 5. Relative Importance Value Index RIV = IVI x 100 / total importance value index of all species (Brandão et al., 1998) and weed dry mass.

\section{Statistical analysis}

Data were submitted to analysis of variance by the F test and, Tukey test, at $5 \%$ probability, was used to compare means when there were significant differences. Weeds were classified according to hierarchical cluster analysis using the Ward method and the Euclidean distance dissimilarity coefficient. The importance value index of weed species was analyzed by the non-hierarchical grouping and the groups were ordered in relation to the type of soil management used, considering the grouping of means (K-means). The correlation coefficients of the variables were estimated and principal component analysis was performed to identify the change factors associated with each soil management system.

\section{Results}

Table 2 summarizes the variance analysis of the data obtained for the number of weeds in the five different soil management systems. It was observed a significant effect on the number of weeds at the different management systems adopted.

It can be noted in Figure 1 that no-till and minimum tillage systems provided the lowest number of weeds, 75 and 98 plants per $\mathrm{m}^{2}$, respectively. The conventional system in turn presented the highest degree of weed infestation and was not effective for weed control. 
Table 2. Summary the variance analysis for the number of weeds in the five soil management systems

\begin{tabular}{c|c|c|c|c}
\hline \multirow{2}{*}{ SV } & \multicolumn{4}{|c}{ Number of Weeds } \\
\cline { 2 - 5 } & DF & MS & TEST “F” & P \\
\hline Soil management & 4 & 17771.20 & $78.77^{* *}$ & $<0,0001$ \\
systems & 3 & 441.60 & 1.96 & 0,1743 \\
BLOCK & 12 & 225.60 & & \\
ERROR & 9.99 & & & \\
VC (\%) & & & \\
\hline
\end{tabular}

***, ns - significant at 5\%,1\% and not significant, respectively, by the ' $\mathrm{F}$ ' test

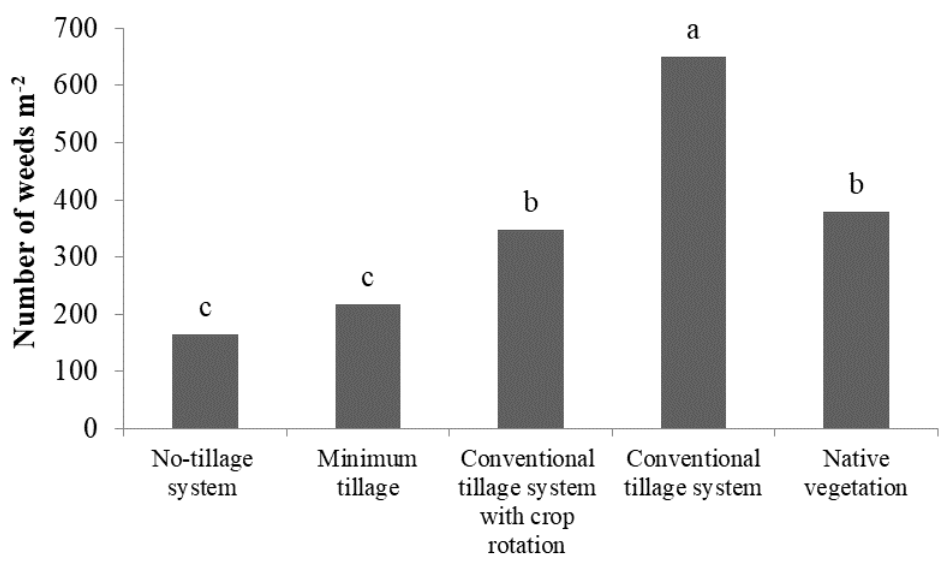

Soil Management Systems

Figure 1. Average number of weeds per square meter in different soil management systems

The phytosociological survey allowed the identification of 10 weed species infesting the experimental area, with predominance of dicotyledonous, distributed in 5 botanical families, being Poaceae the most representative, with 3 species, followed by the families Fabaceae (2) and Rubiaceae (2), representing 30\% (Poaceae), 20\% (Fabaceae) and 20\% (Rubiaceae) (Table 2).

Regarding the characteristics: propagation type, growth habit, life cycle and photosynthetic route there was a higher incidence of sexual, herbaceous, annual and C3 photosynthetic pathway (Table 3), respectively.

Regarding the phytosociological study, at the native vegetation system the highest relative frequencies [RF] were observed for the species Trachypogon plumosus $(38,82)$, Spermacoce capitata $(21,42)$ and Cenchrus echinatus $(17,49)($ Table 3$)$. At the minimum tillage system, the highest relative frequencies (Frr) were from Cyperus flavus (25.19\%), Sida spinosa (15.73\%) and Trachypogon plumosus (15.08\%) species (Table 3). For conventional tillage system, the highest relative frequencies [RF] were observed for Cyperus flavus (28.43\%), Cenchrus echinatus (19.77\%) and Digitaria horizontales (17.39\%) species (Table 2).

In the no-tillage system area, the highest relative frequencies $[\mathrm{RF}]$ were observed for Cyperus flavus (25.85\%), Cenchrus echinatus (18.58\%) and Borreria verticillata $(15.08 \%)$ (Table 3). 
Table 3. Botanical class, family, scientific name, common name, propagation type, growth habit, life cycle, photosynthetic route and EPPO codes of species collected in the cerrado areas of Roraima, Brazil, 2017/2018

\begin{tabular}{|c|c|c|c|c|c|c|c|c|}
\hline Class & Family & Scientific Name & $\begin{array}{c}\text { Common } \\
\text { Name }\end{array}$ & Propagation Type & Growth Habit & Life Cycle & \begin{tabular}{|c|}
$\begin{array}{c}\text { Photosynthetic } \\
\text { Route }\end{array}$ \\
\end{tabular} & $\begin{array}{c}\text { [EPPO] } \\
\text { code }^{1} \\
\end{array}$ \\
\hline \multirow{6}{*}{ Dicotyledonous } & Pedaliaceae & Sesamum indicum & Sesame & Seeds & Herbaceous & Yearly & $\mathrm{C}_{3}$ & SEGIN \\
\hline & Malvaceae & Sida spinosa & Evil & Seeds & Herbaceous & Perennial & $\mathrm{C}_{3}$ & SIDSP \\
\hline & \multirow{2}{*}{ Fabaceae } & Mimosa pudica & $\begin{array}{c}\text { Sleeping } \\
\text { Flower }\end{array}$ & Seeds & Bush & $\begin{array}{l}\text { Yearly or } \\
\text { Perennial }\end{array}$ & $\mathrm{C}_{3}$ & MIMPU \\
\hline & & Desmodium tortuoso & Bug & Seeds & Herbaceous & Yearly & $\mathrm{C}_{3}$ & DEDTO \\
\hline & \multirow{2}{*}{ Rubiaceae } & Spermacoe capitata & Beach poaia & Seeds & Herbaceous & Yearly & $\mathrm{C}_{3}$ & SPCTN \\
\hline & & Borreria verticillata & Friar's Cord & Seeds & Herbaceous & Yearly & $\mathrm{C}_{3}$ & BOIVE \\
\hline \multirow{4}{*}{ Monocotyledonous } & \multirow{3}{*}{ Poaceae } & Cenchrus echinatus & Burr grass & Seeds & Herbaceous & Yearly & $\mathrm{C}_{4}$ & CCHEC \\
\hline & & $\begin{array}{c}\text { Trachypogon } \\
\text { plumosus } \\
\end{array}$ & Borehole & Seeds & Herbaceous & Perennial & $\mathrm{C}_{4}$ & TRNPL \\
\hline & & Digitaria horizontalis & Grass mattress & Seeds & Herbaceous & Perennial & $\mathrm{C}_{4}$ & DIGHO \\
\hline & Cyperaceae & Cyperus Flavus & Tiririca & $\begin{array}{c}\text { Seeds/ } \\
\text { Rhizome }\end{array}$ & Herbaceous & Perennial & $\mathrm{C}_{4}$ & CYPFW \\
\hline
\end{tabular}

${ }^{1}$ [EPPO] code: Also known as the Bayer Code, it is a coding system used by the European and Mediterranean Plant Protection Organization (EPPO) to designate important agricultural plants, pests and pathogens, 2019 
For the conventional tillage system with crop rotation, the highest relative frequencies [RF] were for Cyperus flavus (27.92\%), Cenchrus echinatus (19.77\%) and Sesamum indicum $(15.79 \%)$ species (Table 4).

Table 4. Scientific name, dry mass $[D M]$, relative density [RD], relative frequency $[R F]$, relative abundance [RA], importance value index [IVI] and relative importance value index [RIV] of species in native vegetation, minimum tillage, conventional tillage system, no-tillage system and conventional tillage system with crop rotation on Roraima cerrado, Brazil, $2017 / 2018$

\begin{tabular}{|c|c|c|c|c|c|c|}
\hline Scientific name & $\begin{array}{c}\text { DM } \\
(\mathrm{g})\end{array}$ & $\begin{array}{l}\text { RD } \\
(\%)\end{array}$ & $\begin{array}{c}\text { RF } \\
(\%) \\
\end{array}$ & $\begin{array}{l}\text { RA } \\
(\%) \\
\end{array}$ & IVI (\%) & $\begin{array}{l}\text { RIV } \\
(\%) \\
\end{array}$ \\
\hline \multicolumn{7}{|c|}{ Native Vegetation } \\
\hline Cyperus flavus & 2.33 & 4.6 & 11.83 & 3.55 & 19.98 & 6.66 \\
\hline Cenchrus echinatus & 2.65 & 57.57 & 17.49 & 5.35 & 80.41 & 26.80 \\
\hline Sesamum indicum & 4.65 & 6.64 & 10.44 & 6.57 & 23.65 & 7.88 \\
\hline Spermacoce capitata & 12.54 & 9.91 & 21.42 & 7.65 & 38.98 & 12.99 \\
\hline Trachypogon plumosus & 96.7 & 21.28 & 38.82 & 76.88 & 136.98 & 45.66 \\
\hline Total & & 100.00 & 100.00 & 100.00 & 300.00 & 100.00 \\
\hline \multicolumn{7}{|c|}{ Minimum Tillage } \\
\hline Mimosa pudica & 3.66 & 2.49 & 8.91 & 6.94 & 18.34 & 6.11 \\
\hline Cyperus flavus & 4.23 & 43.74 & 25.19 & 17.98 & 86.91 & 28.97 \\
\hline Desmodium tortuoso & 2.57 & 3.59 & 13.87 & 2.80 & 20.26 & 6.75 \\
\hline Borreria Verticullata & 1.78 & 2.59 & 9.37 & 2.60 & 14.56 & 4.85 \\
\hline Digitaria horizontalis & 3.61 & 33.68 & 11.85 & 14.70 & 60.23 & 20.00 \\
\hline Sida spinosa & 2.79 & 3.76 & 15.73 & 5.26 & 24.75 & 8.25 \\
\hline Trachypogon plumosus & 6.78 & 10.15 & 15.08 & 49.72 & 74.95 & 24.98 \\
\hline Total & & 100.00 & 100.00 & 100.00 & 300.00 & 100.00 \\
\hline \multicolumn{7}{|c|}{ Conventional Tillage System } \\
\hline Mimosa pudica & 1.78 & 3.94 & 9.76 & 1.96 & 15.66 & 5.22 \\
\hline Digitaria horizontalis & 2.67 & 15.71 & 17.39 & 12.93 & 46.03 & 15.34 \\
\hline Sida Spinosa & 3.56 & 4.57 & 3.87 & 2.63 & 11.07 & 3.69 \\
\hline Cyperus flavus & 3.89 & 49.75 & 28.43 & 8.73 & 86.91 & 28.97 \\
\hline Sesamum indicum & 2.57 & 4.47 & 4.65 & 14.44 & 23.56 & 7.85 \\
\hline Cenchrus echinatus & 4.79 & 8.82 & 19.77 & 54.44 & 83.03 & 27.67 \\
\hline Spermacoce capitata & 1.57 & 12.74 & 15.86 & 4.87 & 33.47 & 11.15 \\
\hline Total & & 100.00 & 100.00 & 100.00 & 300.00 & 100.00 \\
\hline \multicolumn{7}{|c|}{ No-tillage System } \\
\hline Digitaria horizontales & 2.58 & 16.77 & 15.72 & 16.94 & 49.43 & 16.47 \\
\hline Cenchrus echinatus & 3.18 & 34.76 & 25.19 & 27.98 & 87.93 & 29.31 \\
\hline Thachypogon plumosus & 3.71 & 13.59 & 13.87 & 17.78 & 45.24 & 15.08 \\
\hline Borreria Verticullata & 1.67 & 10.23 & 19.37 & 12,60 & 42.20 & 14.06 \\
\hline Cyperus flavus & 2.89 & 24.65 & 25.85 & 24.70 & 75.20 & 25.06 \\
\hline Total & & 100.00 & 100.00 & 100.00 & 300.00 & 100.00 \\
\hline \multicolumn{7}{|c|}{ Conventional Tillage System with Crop Rotation } \\
\hline Sesamum indicum & 5.13 & 4.65 & 15.78 & 15.40 & 35.83 & 11.94 \\
\hline Digitaria horizontalis & 2.68 & 17.43 & 15.43 & 18.93 & 51.79 & 17.26 \\
\hline Desmodium tortuosum & 1.60 & 6.87 & 12.47 & 12.63 & 31.97 & 10.65 \\
\hline Cyperus flavus & 3.47 & 39.86 & 27.92 & 23.73 & 91.51 & 30.50 \\
\hline Thachypogon plumosus & 2.76 & 15.76 & 9.82 & 14.44 & 40.02 & 13.34 \\
\hline Cenchrus echinatus & 2.44 & 20.43 & 18.58 & 14.87 & 53.88 & 17.96 \\
\hline Total & & 100.00 & 100.00 & 100.00 & 300.00 & 100.00 \\
\hline
\end{tabular}


The results of the hierarchical cluster analysis are represented in Figure 2. Considering in the dendrogram a break point in the distance of 120, 3 groups were identified. The result of the non-hierarchical cluster analysis is described in Figure 3. Considering the grouping of means [K-means], being $\mathrm{K}=3$, it was found that group 1 , formed by the species Trachypogon plumosus, presented the highest importance value index [IVI] values in the plots under native vegetation and minimum tillage, but with no importance at the conventional soil management system.

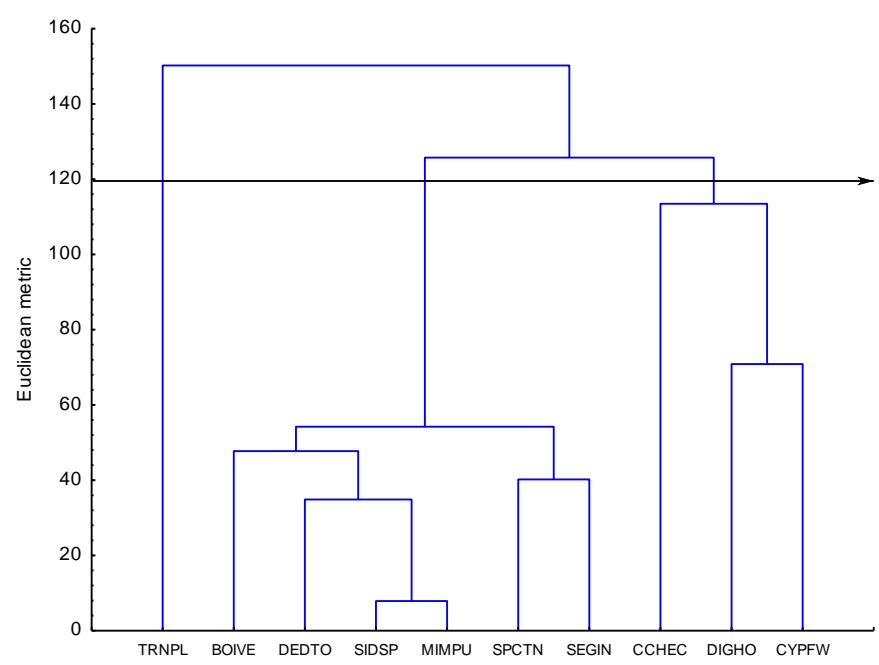

Figure 2. Weed classification by hierarchical cluster analysis by the ward method

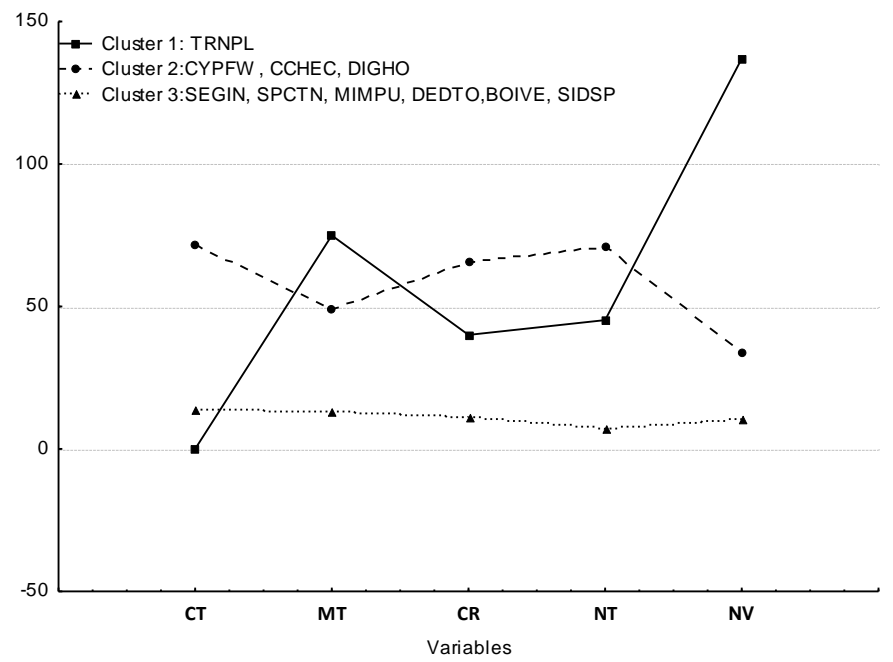

Figure 3. Non-hierarchical cluster analysis containing the ordering of groups in relation to the Weed Species Value Index for each soil management used: Conventional Tillage System [CT], Minimum Tillage [MT], Conventional Tillage System with Crop Rotation [CR], No-Till System [NT] and Natural Vegetation [NV]

Group 2, formed by the species Cyperus flavus, Cenchrus echinatus and Digitaria horizontalis, was characterized by the presence in all treatments, with a high degree of 
[IVI], standing out at the conventional tillage, conventional tillage with crop rotation and no-tillage systems. However, Group 2 presented lower [IVI] in natural vegetation areas.

The first two groups with higher Importance Value Indexes contained species belonging to the botanical families Cyperaceae and Poaceae, and in the second group were the species considered difficult to control in agricultural areas. The third group characterized by greater variability of species and botanical families, presented lower [IVI] than groups 1 and 2 . These results stress the need to identify the weed community in an area and the role of soil management in decision making about weed management.

Principal component analysis was performed to obtain an overview of soil management systems. According to the analysis, $76.78 \%$ of the variation present in the original data was explained by the first two main components [CP1 and CP2] (Table 5). The first major component explained $57.55 \%$ of the total variance and the second $19.23 \%$. According to Teixeira et al. (2012), the first major component always contains the most information from the original values, representing the most relevant results.

Table 5. Coefficient of correlation of variables

\begin{tabular}{c|c|c|c|c|c}
\hline Factor & PC1 & PC2 & PC3 & PC4 & PC5 \\
\hline IVI - Conventional Tillage & 0.778370 & -0.493632 & 0.300139 & -0.110642 & -0.219411 \\
IVI - Minimum Tillage & 0.655918 & 0.263033 & -0.691035 & 0.048281 & -0.143960 \\
IVI - Conventional Tillage with Crop Rotation & 0.918269 & -0.133543 & -0.143805 & -0.261253 & 0.223640 \\
IVI - No-Till & 0.895766 & -0.019263 & 0.196783 & 0.387594 & 0.090987 \\
IVI - Natural Vegetation & 0.442834 & 0.793942 & 0.396137 & -0.119326 & -0.048901 \\
\hline Exploratory variance & 2.8778 & 0.9614 & 0.7839 & 0.2472 & 0.1295 \\
\hline Total variance ratio (\%) & 57.55 & 19.23 & 15.68 & 4.95 & 2.59 \\
\hline
\end{tabular}

Obs.: Variables in bold have significant importance for the respective factor. Equal signs indicate direct, and opposite, indirect relationship

Most soil management systems, with the exception of IVI of weeds from natural vegetation, showed high discriminatory power in the first major component [PC1] (values close to 1) (Table 5). As the factors evaluated have a positive sign, they indicate that rightmost units in the graph (Figure 4) are more influenced by them.

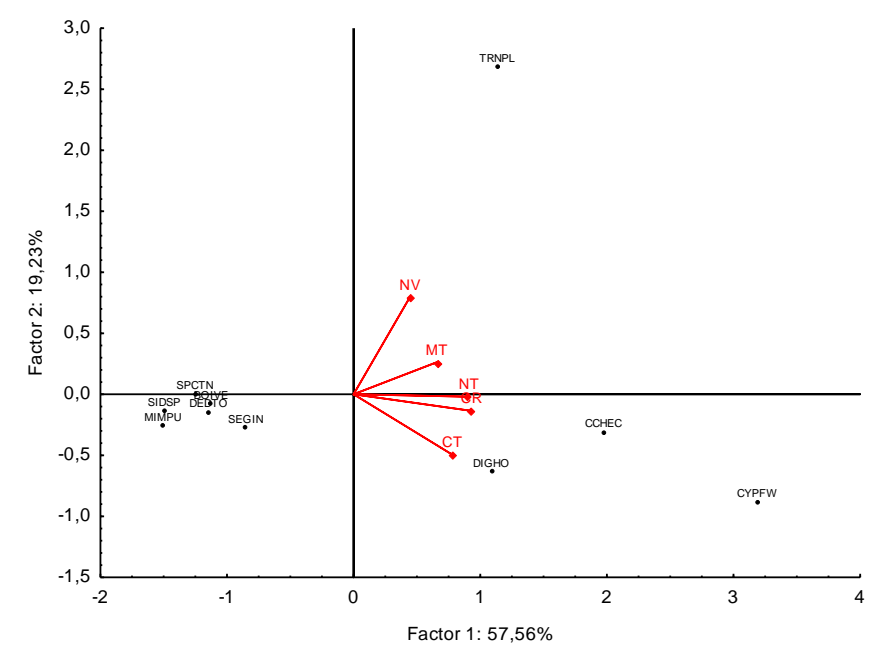

Figure 4. Two-dimensional dispersal of major weed components in different soil management systems: Conventional Tillage System [CT], Minimum Tillage [MT], Conventional Tillage System With Crop Rotation [CR], No-Till System [NT] And Natural Vegetation [NV] 
Figure 4 shows the two-dimensional dispersion of the main components 1 and 2 and the soil management systems. The Trachypogon plumosus species is strongly associated with the natural vegetation soil management system, confirming its segregation verified in cluster analysis and analysis of variance (Figure 3 and Table 5). The species Digitaria horizontalis, Cenchrus echinatus and Cyperus flavus were strongly associated with conventional tillage soil management, either in monoculture or in rotation.

\section{Discussion}

Differentiated soil management practices change the frequency and species of weeds in cultivated areas (Lacerda et al., 2013; Lima et al., 2014). According to Correia et al. (2006), the composition and population densities of weed communities are influenced by soil management systems.

The number of seeds in the soil seed bank of no-tillage system is considered high, but the percentage of seeds that germinate and become competitive can be considered very low (Gomes-Junior and Christoffoleti, 2008).

In phytosociological studies performed, the families Poaceae, Fabaceae and Rubiaceae, respectively, were the ones that prevailed in researches with cultivated species (Marques et al., 2010). The predominance of weed species from the Poaceae family is justified by their high amount of diaspores, propagules that facilitate their spread and hamper their control (Lorenzi, 2008). According to Jakelaitis et al. (2003), for species that reproduce by seeds, the use of agricultural implements provides their spread as well as their distribution in the area.

Among the diversity of Poaceae species that grows in the native areas of Roraima state, Trachypogon plumosus is one of the most important, representing between 70 and $90 \%$ of its botanical composition (Costa et al., 2014). According to Costa et al. (2013), in a native pasture area of Roraima, the species $T$. plumosus appears with great representativeness, between 70 and $90 \%$ of botanical composition. Studies have shown that forage yield of $T$. plumosus is variable and directly influenced by management practices and climatic conditions (Costa et al., 2011, 2013, 2014).

These species were favored by the early practices of ploughing and harrowing, which promoted the spread of their seeds. According to Santiago et al. (2007), some weeds are favored by the cultivation system, such as the morning glory (Ipomoea grandifolia).

Regarding the Fabaceae family, similar studies performed in the Cerrado of Roraima concluded that $87 \%$ of the diversity of species found belongs to this family (Flores and Rodrigues, 2010). Several other works on identification of weeds report the Fabaceae family as the most representative in diverse cultivated areas (Albuquerque et al., 2013, 2014; Gomes et al., 2014; Lima et al., 2014; Evangelista et al., 2015).

The floristic composition of the weed community and its distribution can be altered based on the dynamics between species, climatic conditions, cultural methods and soil management.

It is generally believed that $\mathrm{C}_{4}$ plants are more efficient than $\mathrm{C}_{3}$, however it depends on several aspects (Silva et al., 2007). $\mathrm{C}_{4}$ plants require higher energy levels for the production of photoassimilates, as they have two carboxylative systems and therefore need to recover two enzymes for a new photosynthetic cycle. All energy comes from light; if $\mathrm{C}_{4}$ plants do not have access to adequate levels of irradiance, they tend to be more affected by light energy competition than $\mathrm{C}_{3}$ plants (Concenço et al., 2013). 
According to Ferreira et al. (2007), the liming practice generally favors the increase of noxious weeds in no-tillage systems, due to higher $\mathrm{pH}$ and calcium content in the topsoil.

According to Albuquerque et al. (2013), for the agrarian sciences professional to recommend the appropriate management system on a farm, he must have basic knowledge on several weed characteristics, including propagation type, life cycle, growth habit, photosynthetic route, as well as identification of species in the young phase.

\section{Conclusion}

No-till and minimum tillage systems have the lowest number of weed infestations.

Among the species collected in the area, the botanical families Poaceae, Fabaceae and Rubiaceae are the most representative.

The type of soil management system adopted has a direct influence on the weed community.

About relative frequency, the species Cyperus flavus does not stand out in native vegetation only.

Future studies are needed to improve weed control efficiency even in soil management systems with lower weed infestations.

\section{REFERENCES}

[1] Albuquerque, J. A. A., Melo, V. F., Soares, M. B. B., Finoto, E. L., Siqueira, R. H. S., Martins, S. A. (2013): Phytosociology and morphological characteristics of weeds after corn cropping on conventional till in the savanna of Roraima. - Revista Agro@mbiente On-line 7(3): 313-321.

[2] Albuquerque, J. A. A., Evangelista, M. O., Mates, A. P. K., Alves, J. M. A., Oliveira, N. T., Sediyama, T., Silva, A. A. (2014): Occurrence of weeds in cassava savanna plantations in Roraima. - Planta Daninha 32(1): 91-98.

[3] Alcantara Neto, F., Oliveira Junior, J. O. L., Bezerra, A. A. C., Silva Junior, G. B., Albuquerque, J. A. A., Zuffo, A. M., Aquino, J. P. A., Borges, A. F. (2019): Floristic composition of weeds in a dystrophic Red-Yellow Argisol under the cultivation of cowpea, cv. BRS Novaera. - Australian Journal of Crop Science 13: 767-772.

[4] Brandão, M., Brandão, H., Laca-Buendia, J. P. (1998): A mata ciliar do rio Sapucaí, município de Santa Rita do Sapucaí-MG: fitossociologia. - Daphne 8(4): 36-48.

[5] Braun-Blanquet, J. (1979): Fitosociologia: bases para el estudio de las comunidades vegetales. $-\mathrm{H}$. Blume, Madrid.

[6] Concenço, G., Motta, I. S., Correia, I. V. T., Silva, F. M., Salomão, G. B. (2013): Infestation of spontaneous species in monocrop coffee or intercropped, under agroecological system. - Agrarian 6(19): 22-28.

[7] Correia, N. M., Durigan, J. C., Klink, U. P. (2006): Influence of type and amount of crop residues on weed emergence. - Planta Daninha 24(2): 245-253.

[8] Costa, N. D. L., Gianluppi, V., Moraes, A. D. (2011): Forage production and morphogenesis of "Trachypogon vestitus" under diferente regrowth ages in the Roraima's savannas. - Revista Brasileira de Saúde e Produção Animal 12(4): 935-948.

[9] Costa, N. D. L., Moraes, A. D., Carvalho, P. C. D. F., Monteiro, A. L. G., Oliveira, R. A. D. (2013): Morphogenic and structural traits of Trachypogon plumosus according to soil fertility and defoliation level. - Pesquisa Agropecuária Brasileira 48(3): 320-328.

[10] Costa, N. L., Moraes, A., Gianluppi, V., Bendahan, A. B. (2014): Evaluation of natural regrowth of Trachypogon plumosus in a native pasture of Roraima's Savannas. - Scientia Agraria Paranaensis 13(1): 57-64. 
[11] Cruz, D. L. S., Rodrigues, G. S., Dias, F. O., Alves, J. M. A., Albuquerque, J. A. A. (2009): Weeds survey of rotational crops of soybean, corn, and irrigated rice in the savannah (cerrado) of Roraima. - Revista Agro@ mbiente On-line 3(1): 58-63.

[12] Délye, C., Jasieniuk, M., Le Corr, V. (2013): Deciphering the evolution of herbicide resistance in weeds. - Trends Genet 29(11): 649-58.

[13] Evangelista, M. O., Albuquerque, J. A. A., Santos, S. D., Alves, J. M. A., Santos, T. D., Castro, T. S., Neto, F. D. A. (2015): Fitossociologia de plantas espontâneas em produção orgânica de hortaliças no estado de Roraima. - Sodebras 10(117): 259-266.

[14] Ferreira, O. G. L., Siewerdt, L., Medeiros, R. B., Levien, R., Favreto, R., Pedroso, C. E. S. (2007): Soil chemical attributes and seed bank spontaneous species regeneration in native grassland under different cultivation systems. - Revista Brasileira de Agrociência 13(1): 81-89.

[15] Flores, A. S., Rodrigues, R. S. (2010): Leguminosae diversity in a savanna area of Roraima, Brazil. - Acta Botanica Brasilica 24(1): 175-183.

[16] Gomes, D. S., Bevilaqua, N. C., Silva, F. B., Monquero, P. A. (2014): Weed suppression by sunn hemp and sorghum cover crop. - Revista Brasileira de Agroecologia 9(2): 206213.

[17] Gomes-Junior, F. G., Christoffoleti, P. J. (2008): Weed biology and management in notillage areas. - Planta Daninha 26(4): 789-798.

[18] Jakelaitis, A., Ferreira, L. R., Silva, A. A., Agnes, E. L., Miranda, G. V., Machado, A. F. L. (2003): Weed population dynamics under different corn and bean production systems. Planta Daninha 21(1): 71-79.

[19] Junior, L. B. B., Carvalho, F. L. C., Sousa, R. R., Araújo, R. L., Barros, W. K. F. C., Veras, F. H. C., Silva, R. B. (2019): Avaliação da cultura da mandioca em diferentes sistemas de manejo do solo. - Global Science and Technology 12(2): 152-169.

[20] Lacerda, K. A. P., Cordeiro, M. A. S., Verginassi, A., Salgado, F. H. M., Paulino, H. B., Carneiro, M. A. C. (2013): Organic carbon, biomass and microbial activity in an Oxisol under different management systems. - Revista de Ciências Agrárias/Amazonian Journal of Agricultural and Environmental Sciences 56(3): 249-254.

[21] Lima, L. K. S., Silva, J. S., Santos, J. P. S., Araújo, A. E., Lopes, M. D. F. Q. (2014): Vegetative growth of yellow passion fruit subjected to different forms of training and pruning for renovation. - Agropecuária científica no semiárido 10(2): 72-76.

[22] Lima, S. F., Timossi, P. C., Almeida, D. P., Silva, U. R. (2014): Phytosociology of weeds in convivencewith cover crops. - Revista Caatinga 27(2): 37-47.

[23] Lorenzi, H. (2000): Plantas Daninhas do Brasil: terrestres, aquáticas, parasitas e tóxicas. Platarum, Nova Odessa, SP.

[24] Lorenzi, H. (2008): Plantas Daninhas do Brasil: terrestres, aquáticas, parasitas e tóxicas. Platarum, Nova Odessa, SP.

[25] Lorenzi, H. (2014): Manual de Identificação e Controle de Plantas Daninhas - Plantio Direto e Convencional. - Platarum, Nova Odessa, SP.

[26] Marques, L. J. P., Silva, M. R. M., Araújo, M. S., Lopes, G. S., Corrêa, M. J. P., Freitas, A. C. R., Muniz, F. H. (2010): Floristic composition of weeds in the cowpea (Vigna unguiculata) culture under the chopped secondary forest system. - Planta Daninha 28: 953961.

[27] Menezes, P. H. S., Albuquerque, J. A. A., Smiderle, J. O., Medeiros, R. D., Alves, J. M. A., Gianluppi, D. (2019): Occurrence of Weeds in Areas Submitted to Tillage Managements for Soybean Cultivation in the Cerrado of Roraima. - Planta Daninha 37: e019193014.

[28] Moreira, H. J. C., Bragança, H. B. N. (2010): Manual de Identificação de Plantas Infestantes - Cultivos de Verão. - FMC Agricultural Products, Campinas, SP.

[29] Santiago, A. D., Rossetto, R. (2007): Preparo convencional. - Disponível em: http://www.agencia.cnptia.embrapa.br. Acessado em 3 Abr 2019. 
[30] Silva, A. A., Ferreira, F. A., Ferreira, L. R., Santos, J. B. (2007): Biologia de plantas daninhas. - In: Silva, A. A., Silva, J. F. (eds.) Tópicos em manejos de plantas daninhas. UFV, Viçosa, MG.

[31] Vale Júnior, J. F., Schaefer, C. E. G. R. (2010): Solos Sob Savanas de Roraima: gênese, classificação e relações ambientais. - Gráfica Ioris, Boa Vista, 219p. 